\title{
MELINDUNGI ANAK DARI KONTEN NEGATIF INTERNET: Studi terhadap Peramban Web Khusus Anak
}

\author{
Masyari Ulinnuha \\ Fakultas Dakwah dan Komunikasi \\ IAIN Walisongo Semarang
}

\begin{abstract}
Abstrak
Dunia teknologi dan internet berkembang sangat pesat di dunia, tak terkecuali Indonesia. Imbasnya, jumlah pengguna internet saat ini semakin besar dan bertambah terus setiap harinya. Sebagian dari pengguna internet tersebut adalah anak-anak. Sementara banyak sekali situs web yang tidak layak menjadi konsumsi anakanak. Untuk itu diperlukan pembatasan bagi anak-anak dalam mengakses situs web.Tulisan ini membahas beberapa peramban web khusus anak. Ada 4 peramban yang dibahas yaitu KidZui, Hoopah Kidview Computer Explorer, Peanut Butter PC dan NoodleNet. Keempat peramban tersebut dengan segala kelebihannya bisa menjadi alternatif untuk membatasi anak dari dunia internet yang sangat luas. Namun keempat peramban tersebut tetap mempunyai kelemahan sehingga peran orang tua tetap diperlukan agar anak tidak terjebak ke dalam situs yang tidak layak.
\end{abstract}

Kata Kunci: anak, internet, peramban web

\section{A. Pendahuluan}

Dunia teknologi dan internet berkembang sangat pesat di dunia, tak terkecuali Indonesia. Imbasnya, jumlah pengguna internet saat ini semakin besar dan bertambah terus setiap harinya. Jumlah pengguna internet di Indonesia menguasai Asia sebesar 22,4 \%. ${ }^{1}$ Internet dalam era informasi telah menempatkan dirinya sebagai salah satu pusat informasi yang dapat diakses dari

1 lik Novianto, "Perilaku Penggunaan Internet di Kalangan Mahasiswa (Studi Deskriptif tentang Perilaku Penggunaan Internet di Kalangan Mahasiswa Perguruan Tinggi Negeri (FISIP Unair) dengan Perguruan Tinggi Swasta (FISIP UPN) untuk Memenuhi Kebutuhan Informasinya)", Jurnal Libri-Net, Vol. 2 - No. 1 / 2013-01. 
berbagai tempat tanpa dibatasi oleh ruang dan waktu. Internet disebut sebagai pusat informasi bebas hambatan karena dapat menghubungkan satu situs informasi ke situs informasi lainnya dalam waktu yang singkat.

Tidak seperti beberapa tahun silam, anak-anak masa kini sudah mulai terbiasa dengan internet. Kaspersky Lab mencatat ada begitu banyak percobaan dari anak-anak ke situs yang belum sesuai dengan umur mereka. Kaspersky Lab mencatat ada beberapa kategori konten internet yang seharusnya belum boleh diakses oleh anak-anak. Tiga jenis konten "tidak sesuai umur" yang paling banyak dicoba adalah konten pornografi dan erotis, jejaring sosial, dan perangkat lunak ilegal. Masih menurut Kaspersky Lab, percobaan untuk mengakses situs pornografi, dalam skala global, memiliki persentase yang paling besar. Setiap bulan, ada 60 juta percobaan untuk mengakses situs pornografi atau hampir empat kali lipat dibandingkan kategori di tempat kedua, yaitu jejaring sosial. Di Amerika Serikat dan Inggris, kategori konten judi di kedua negara ini juga menjadi yang paling tinggi jika dibandingkan dengan rata-rata global. Jerman menjadi negara teratas dalam kategori konten pornografi dan erotis dengan persentase 80 persen. Nilai tersebut jauh melebihi angka persentase global yang mencapai 53,6 persen.

Memang tidak bisa dipungkiri sebagai individu dari sebuah masyarakat era modern, kehidupan sehari-hari kita tidak akan terlepas dari teknologi, termasuk internet. Anak-anak kecil bahkan anak SD sudah mahir menggunakan internet. Banyak hal positif yang bisa diambil dari pemanfaatan internet tersebut, seperti akses informasi yang sangat cepat serta bisa berkomunikasi dengan berbagai teman dari belahan dunia manapun. Tapi yang tidak boleh kita lupakan juga bahwa teknologi tersebut mempunyai dampak negatif apabila penggunaannya tidak disertai dengan nilai-nilai. Sehingga selain diberikan pemahaman tentang nilai-nilai yang baik dan buruk agar anak bisa menyaring mana informasi yang bermanfaat dan mana yang tidak boleh diketahuinya, perlu juga kita melakukan pengawasan yang cukup terhadap anak-anak kita.

Berdasarkan hasil survei Asosiasi Penyelenggara Jasa Internet Indonesia (APJII), jumlah pengguna internet di Indonesia di tahun 2012 ini 
sudah mencapai angka 63 juta. Penetrasinya sudah mencapai 24,23\% dari total populasi penduduk Indonesia. Perkembangan jumlah pengguna internet terus mengalami peningkatan. Tahun 2009 tercatat jumlah pengguna Internet di Indonesia berjumlah 30 juta pengguna, 2010 sebanyak 42 juta, 2011 mencapai 55 juta, dan di 2012 ini mencapai 63 juta. Angka ini jelas merupakan potensi yang luar biasa.

Weny Rochmawati mengutip dari Anne dan Glenn menegemukakan bahwa, persentase anak-anak mengakses Internet dengan usia (5-8 tahun) di Australia adalah anak-anak usia 5 tahun sebanyak 20,6\%, anak-anak usia 6 tahun sebanyak 33,4\%, anak-anak usia 7 tahun sebanyak $42,2 \%$, anak-anak usia 8 tahum sebanyak 52,6\%. Dari data ini dapat disimpulkan bahwa jumlah anak yang mengakses internet kian hari kian meningkat. Tren ini tentu saja juga berlaku di Indonesia.

Dalam penelitiannya Weny Rochmawati menyampaikan bahwa ${ }^{2}$ penggunaan internet di kalangan anak-anak internet merupakan sebuah kepentingan yang sangat dibutuhkan oleh mereka. Dalam sebuah kepentingan baik kepentingan berupa hiburan maupun kepentingan berupa akademik dalam menggunakan internet dan penggunaannya yang sangat luas sesuai dengan kebutuhan anak-anak dan berhubungan dengan hal-hal yang positif, seperti dalam penggunaan internet yang berhubungan dengan akademik anak-anak dapat mencari artikel-artikel tentang tugas-tugas sekolah mereka dan juga mencari situs-situs yang berhubungan dengan fun atau leisure. Anak-anak lebih menyukai untuk membuka situs-situs atau alamat website yang berhubungan dengan kepentingan fun atau leisure, mereka tidak mengutamakan kepentingan yang berhubungan dengan kegiatan akademik mereka di sekolah. Mereka lebih memilih untuk membuka situs-situs yang berhubungan dengan musik, film dan lain sebagainya. Selain memanfaatkan internet untuk kepentingan hiburan, anak-anak juga memanfaatkan internet untuk kepentingan akademik, dimana untuk memenuhi keperluan sekolahnya dan mencari tugas sekolah anak-anak mencari informasi melalui

${ }^{2}$ Weny Rochmawati, “Perilaku Pemanfaatan Internet (Internet Utilization of Behavior) (Studi Deskriptif tentang Pemanfaatan Internet untuk Kepentingan Hiburan dan Akademik di Kalangan Anak-anak di Kota Surabaya)", Jurnal Libri-Net, Vol. 1 - No. 1 / 2012-12. 
internet dan bentuk informasi yang paling sering di cari adalah sumber informasi yang berupa email.

Puspita Adiyani Candra dalam penelitiannya mengemukakan bahwa anak-anak di Indonesia mulai mengenal internet dalam usia yang sangat muda. Kebanyakan mulai mengenal internet pada usia 6-8 tahun, namun tidak sedikit pula yang sudah mulai mengenal internet pada usia yang lebih muda. Bahkan ada yang berkenalan dengan internet saat usianya baru 3 tahun. Mayoritas dari mereka mengenal internet melalui perkenalan dalam lingkungan pendidikan informal, yaitu rumah lewat orang tua, saudara bahkan eyangnya. Lokasi yang paling banyak digunakan untuk mengakses internet pun juga tidak jauh berbeda, mengakses di rumah menjadi opsi yang paling banyak dipilih. Anak-anak late childhood kebayakan masih tergolong light user dalam menggunakan internet. Artinya, mereka hanya mengakses internet kurang dari 7 jam per minggu. Hanya 9\% diantaranya yang menjagi high user. Kebanyakan, mereka mengakses internet dengan durasi yang panjang di akhir pekan. Hal ini menunjukkan bahwa anak-anak generasi ini mempunyai cara yang tidak sama dalam menggunakan leisure time dari generasi sebelumnya, yang lebih suka bermain di luar secara fisik.

Lokasi penggunaan mempengaruhi bagaimana anak-anak menggunakan internet, didapati bahwa lokasi akses mempengaruhi eksplorasi. Di rumah, durasi penggunaan internet oleh anak-anak lebih lama ketimbang di sekolah dan area publik informal. Kegiatan yang dilakukan pun lebih banyak dan variatif. Berbeda dengan disekolah yang masih terikat kurikulum. Anakanak tidak dapat dipisahkan dari bermain game hal ini terkait dengan proses perkembangannya. Yang menarik, dalam aktivitas online ini adalah anakanak telah menemukan cara baru untuk mengkonsumsi sesuatu dengan memanfaatkan internet, dengan belanja online. Area publik informal yang sering digunakan oleh anak-anak adalah warnet dan kafe/ restoran. ${ }^{3}$

Semakin banyaknya anak-anak yang menakses internet tentu membawa kekhawatiran tersendiri. Orang tua tentu khawatir anak-anak mereka akan

${ }^{3}$ Puspita Adiyani Candra, "Penggunaan Internet pada Anak-anak Sekolah Usia 6-12 Tahun di Surabaya", Jurnal Commonline, Vol. 1-No. 2 / 2013-02. 
mengakses situs-situs yang tidak layak menjadi konsumsi anak-anak. Salah satu yang menjadi perhatian adalah akses terhadap konten pornografi di internet. Hal ini akan sangat mudah terjadi dengan banyaknya situs pornografi di internet. Sebuah data yang dipublikasikan oleh toptenreviews.com menyebutkan bahwa ada 4,2 juta situs porno di internet. Jumlah laman porno di internet mencapai 420 juta. Yang mengkhawatirkan, pengakses situs porno di Indonesia juga sangat besar, bahkan Menkominfo menyebutkan bahwa Indonesia adalah pengakses situs pornografi terbesar kedua di dunia.

Penelitian yang dilakukan oleh Kandi Aryani mengungkapkan bahwa remaja menganggap pornografi sebagai sesuatu yang tidak bermoral dan melanggar nilai serta norma yang berlaku di masyarakat Indonesia. Pendapat remaja ini mengacu dan disesuaikan dengan standar moral serta mengikuti pendapat dominan yang berlaku di masyarakat secara umum. Tetapi pendapat ini ternyata menjadi berbeda dan bisa dikatakan tidak sejalan ketika ditanyakan mengenai sikap mereka terhadap pornografi dan keberadaan situ-situs seks di internet. Pornografi diapandang sebagai sesuatu yang tidak bisa dihindari keberadaannya. Remaja memilih bersikap untuk tidak melarang keberadaan pornografi di internet dan menganggapnya sebagai sesuatu yang sah-sah saja, apalagi bagi beberapa remaja, pornografi juga dianggap memberikan manfaat sebagai hiburan atau refreshing. ${ }^{4}$ Katharina Ambarwati menemukan bahwa para pengakses situs porno cenderung memiliki perilaku yang negatif dan juga memiliki perilaku seksual yang menyimpang.

Banyaknya anak yang mengakses internet serta banyaknya situs-situs web yang tidak aman untuk anak membuat para orang tua berusaha membatasi akses anak terhadap internet. Salah satu caranya adalah dengan menyediakan peramban web khusus untuk anak-anak. Dalam makalah ini akan dibahas beberapa peramban web yang dirancang agar anak-anak dapat mengakses situs web secara aman.

${ }^{4}$ Kandi Aryani S., "Penerimaan Remaja terhadap Wacana Pornografi dalam Situssitus Seks di Media Online", Jurnal Penelitian Dinamika Sosial, Vol. 7 - No. 2 / 2008-08. 


\section{B. Peramban Web untuk Anak}

Ada banyak perusahaan yang mengembangkan peramban web khusus anak. Namun dalam makalah ini hanya dibahas 4 peramban saja yaitu KidZui, Hoopah Kidview Computer Explorer, Peanut Butter PC dan NoodleNet.

\section{KidZui}

Kebanyakan perangkat lunak parental control melakukan pembatasan yang ketat ketika anak mengakses internet, juga membatasi apa saja yang bisa dilakukan oleh anak. Kebanyakan anak akan mencoba untuk melepaskan diri dari batasan-batasan ini. Mereka mengerahkan daya dan upaya untuk bisa lepas dari kontrol orang tua. KidZui menerapkan pendekatan yang berbeda. KidZui menciptakan peramban bebas yang melibatkan anak secara atraktif sehingga anak tidak lagi berminat untuk keluar dari wilayah KidZui. Untuk anak pra-sekolah atau anak yang belum familiar dengan internet, hal ini akan sangat efektif. Tetapi untuk anak-anak yang lebih berpengalaman, efektivitasnya bisa semakin berkurang.

Ketika memulai KidZui, anak diminta membuat avatar yang disebut Zui. KidZui memberikan pilihan jenis kelamin, warna kulit, perwajahan dan pakaiannya. Setiap Zui membutuhkan nama yang harus berbeda dengan semua nama yang dipakai oleh pengguna KidZui. Kata kuncinya (password) juga harus unik. Pilihan umur mulai 3 sampai 17 tahun meskipun produk ini sebenarnya menyasar anak-anak berusia 3-12 tahun. Persetujuan dari Zui yang baru didapatkan dengan cara aktifasi melalui email oleh orang tua.

Untuk masuk ke KidZui, anak tinggal mengeklik Zui mereka di jendela log-in. Perambannya sendiri tidak membutuhkan password. Jika KidZui ini dipakai oleh beberapa anak, lebih baik anak yang lebih tua memakai password untuk Zui-nya. Dengan demikian anak yang lebih kecil tidak bisa memakai Zui kakaknya. KidZui dan Peanut Butter PC tidak membatasi jumlah anak yang bisa memakainya, sedangkan NoodleNet membatasinya sampai 5 saja. Hanya 8 Zui yang ditampilkan pada halaman log-in. Kalau ditambahkan satu Zui lagi, maka Zui yang pertama kali dibuat akan hilang dari halaman log-in. Akan tetapi pemilik Zui yang pertama tetap dapat masuk ke KidZui dengan cara mengetikkan nama pengguna (nama Zui) dan 
password. Jadi, Zui yang pertama ini lebih cocok untuk anak-anak yang sudah lebih berpengalaman.

\section{a. Peramban KidZui}

Seperti NoodleNet dan Peanut Butter PC, KidZui mengontrol akses internet anak dengan mengganti perambannya. Namun KidZui berbeda dengan NoodleNet dan Peanut Butter PC. KidZui tidak mengizinkan anak untuk mengakses program-program windows lainnya. Setelah masuk (log-in), beranda laman beranda KidZui menampilkan gambar thumbnail dari situs web yang populer, foto atau video yang sesuai dengan usia anak. Tampilan ini diperbarui setiap 5 sampai 10 detik. Gambar-gambar ini ditampilkan secara dinamis sehingga menarik perhatian anak. Ketika anak mengeklik salah satu gambar thumbnail tersebut, akan ditampilkan konten yang tersedia. Tampilan berupa gambar ini sangat memudahkan anak-anak untuk mengakses konten yang mereka inginkan.

Kolom-kolom di bagian atas menampilkan beberapa kategori yang bisa dieksplorasi oleh anak. Dengan memilih sebuah kategori akan ditampilkan situs-situs web yang sesuai. Juga akan ada daftar situs yang terkait dengan kategori tersebut. Anak-anak bisa mengetikkan alamat web yang ingin dikunjungi, akan tetapi mereka hanya dizinkan untuk mengakses situs web yang telah disetujui oleh tim KidZui. Ada sekitar 600.000 situs web yang diizinkan. Apabila anak ingin mengakses situs yang tidak diblok oleh $K i d Z u i$, anak dapat meminta izin pada orang tua. Selanjutnya orang tua bisa memberikan izin melalui akun orang tua di KidZui.

Anatarmuka KidZui tidak seperti NoodleNet yang berubah sesuai dengan usia anak. Tampilan KidZui sama untuk semua anak. Elemenelemen antarmuka memberikan respos berupa gerakan maupun bunyi ketika dilewati panah tetikus. Antarmuka berupa gambar dan teks. Dengan demikian anak-anak yang belum bisa membacapun dapat menikmati peramban KidZui.

Anak-anak yang lebih muda akan menghabiskan banyak waktunya untuk menjelajahi kategori-kategori yang ada. Banyaknya permainan, kartun dan video akan menarik perhatian anak-anak yang lebih besar. Akan 
tetapi anak-anak yang sudah cukup besar akan mengetik alamat web atau melakukan pencarian terhadap web-web tertentu, kemudian mereka akan kecewa karena tidak dapat mengakses situs web yang mereka inginkan. Di sinilah peran orang tua diperlukan. Orang tua dapat mengizinkan akses terhadap situs-situs aman yang diinginkan oleh anak. Apabila hal ini tidak dilakukan, anak bisa saja merasa bosan dan kemudian beralih menggunakan peramban yang lain. Selain kebijaksanaan orang tua dalam memberikan izin akses ke situs-situs yang secara default diblok oleh KidZui, juga diperlukan cara lain agar anak tidak berpindah ke peramban lain. Misalnya dengan cara mengaktifkan parental control di sistem operasi.

Program-program parental control lain seperti Net Nanny dan Safe Eyes mengontrol berapa lama anak dapat menggunakan komputer dan mengakses internet. Orang tua juga dapat menentukan waktu yang diperbolehkan bagi anak untuk menggunakan komputer. NoodleNet menggunakan kontrol yang sedikit berbeda, orang tua dapat menentukan berapa lama anak dapat menggunakan komputer pada satu kali pemakaian dan berapa lama anak harus melakukan hal lain sebelum diperbolehkan menggunakan komputer lagi. KidZui tidak menyertakan fasilitas untuk mengontrol waktu penggunaan komputer. Alih-alih membatasi waktu, KidZui malah berusaha agar anak bertahan mengakses internet namun tetap berada dalam wilayah KidZui. Hal ini ditunjukkan dengan tampilan antarmuka yang dibuat semenarik mungkin.

\section{b. Jejaring Sosial}

Setiap Zui bukan cuma menajadi penanda di laman log-in, akan tetapi juga merupakan wajah anak di dunia pertemanan KidZui. Sistem pertemanan di dunia KidZui mirip dengan sistem pengirim pesan instan (misal Yahoo! Messanger). Anak dapat menambahkan teman diskusi dengan menekan kotak "Add Friend". Anak lain yang diminta menjadi teman bisa menerima untuk kemudian berkomunikasi dua arah atau bisa juga memilih untuk menolak pertemanan.

Apabila anak sudah terhubung dengan beberapa teman, maka terjadilah semacam jejaring sosial. Mereka bisa berbagi situs web, foto atau video 
yang mereka temukan di KidZui. Hal ini dapat mereka lakukan dengan hanya membuka menu share kemudian mengeklik pada satu orang teman atau lebih. Situs web, foto atau video yang dibagikan akan terlihat di kotak masuk (inbox) teman. Tidak ada pemberitahuan jika ada hal baru yang dibagikan. Tidak ada bedanya antara item yang baru dengan yang lama. Tidak ada fasilitas untuk menghapus item tersebut dari kotak masuk. Dengan demikian, anak yang suka bersosialisasi di dunia maya harus sering mengecek kotak masuknya. Anak-anak tidak dapat berbagi informasi pribadi apapun. Anak dapat merekomendasikan laman, foto atau video yang mereka temukan. Mereka juga bisa mendaftarkan pendapatnya terhadap laman, foto atau video yang diberikan.

Untuk menarik perhatian anak terhadap internet, KidZui mengarahkan anak untuk melakukan berbagai aktivitas. Anak diarahkan untuk mengunjungi situs web, melakukan pencarian, berteman dengan anak lain, berbagi dengan teman, menandai item, melihat laman web, foto dan video. Anak dapat mengeklik ikon Zui dari teman-temannya untuk mengetahui total poin yang mereka dapatkan. Pada versi premium, banyaknya poin menunjukkan level keanggotaan.

\section{Hoopah Kidview Computer Explorer}

Orang tua tentu menginginkan anak-anaknya aman dari pengaruh negatif penggunaan komputer. Akan tetapi orang tua tidak mungkin melarang anak untuk menggunakan komputer. Dengan memencet tombol keyboard secara acak, bisa jadi anak menghapus berkas-berkas yang ada, membuat sistem operasi berhenti bekerja dan bahkan bisa mengakses situs porno di internet. Hoopah Kidview Computer Explorer memungkinkan anak menggunakan komputer secara aman. Anak tidak bisa mengakses berkasberkas yang ada di komputer dan juga terhindar dari situs-situs internet yang tidak baik. Hoopah bisa dipakai untuk membatasi akses email hanya pada kontak yang diperbolehkan saja. Hoopah dirancang untuk anak berusia 2 sampai dengan 10 tahun.

Pada saat proses instalasi, Hoopah meminta orang tua untuk menambahkan anak-anak yang akan menggunakannya, menuliskan namanya, 
tanggal lahirnya dan menentukan gambar bagi tiap anak. Gambar yang disediakan oleh Hoopah ini sangat terbatas, namun demikian orang tua bisa menggunakan gambar lain dari berkas yang sudah ada di komputer. Hoopah mengkonfigurasi setting berdasarkan usia anak secara otomatis. Setting ini masih dapat diubah oleh orang tua. Beberapa perangkat lunak tambahan yang diperlukan oleh Hoopah akan otomatis diinstal pada saat proses instalasi Hoopah. Setelah instalasi selesai, anak-anak bisa menggunakan komputer dengan aman.

Hoopah bisa mengubah tampilan antarmuka sesuai dengan usia anak. Untuk anak-anak yang masih kecil, Hoopah membatasi akses internet pada sejumlah situs web yang aman. Situs-situs tersebut dikelompokkan menjadi beberapa kategori yaitu sains, matematika, permaianan dan seni. Tiap kategori dikenali menggunakan gambar. Hoopah juga menghilangkan popup maupun iklan yang ada dalam situs. Dengan demikian Hoopah mengubah tampilan situs agar terbebas dari tampilan-tampilan yang tidak baik bagi anak. Untuk permainan, Hoopah akan menggunakan tampilan layar penuh (fullscreen).

Kebanyakan anak suka menggambar, karena itu Hoopah menyertakan perangkat aplikasi untuk menggambar yang disediakan oleh Crayola. Anakanak bisa memilih sembilan alat gambar yang ada dan memberikan warna dengan menggunakan tetikus. Dengan mengeklik logo Crayola, anak-anak akan terhubung ke situs web Crayola. Tentu saja iklan-iklan tetap tidak akan terlihat oleh anak. Gambar-gambar yang dibuat oleh anak bisa dicetak, namun tidak dapat disimpan dalam bentuk berkas.

Ikon situs web dan beberapa tombol akan bersuara jika dilewati kursor tetikus, akan tetapi menu-menu di desktopnya statis. Tiga dari lima item desktop yaitu nameplate, picture dan clock benar-benar tidak interaktif. Sedangkan dua lainnya digunakan untuk mengaktifkan aplikasi menggambar dan email. Sebagian besar layar desktop akan tetap kosong sampai anak membuaka situs web atau program yang dikontrol oleh orang tua. Antarmuka Hoopah lebih responsif dibandingkan Peanut Butter PC, namun tidak seperti KidZui maupun NoodleNet yang penuh animasi. 
Anak-anak usia sekolah mendapatkan desktop yang sama tetapi lebih banyak konten yang bisa mereka jelajahi. Hoopah menghitung usia anak berdasarkan tanggal lahirnya. Untuk anak kelas $3 \mathrm{SD}$, Hoopah memberikan anatarmuka yang baru yaitu kotak untuk memasukkan alamat internet dan mesin pencari. Anak-anak bisa menjelajah situs web yang mereka inginkan dengan mengetikkan alamatnya. Namun situs web yang bisa dikunjungi hanya situs yang tidak diblok oleh Hoopah. Mesin pencari yang disediakan adalah Google yang disetel permanen pada mode SafeSearch. Dengan demikian anak masih aman berselancar di dunia maya. Hoopah masih memblok pop-up dan kebanyakan banner iklan. Hoopah menampilkan peringatan jika ada situs web yang diblok.

\section{a. Wilayah Orang Tua}

Untuk masuk laman untuk orang tua diperlukan password administrator. Hoopah dapat disetel agar langsung dijalankan saat komputer mulai dihidupkan dan untuk keluar harus menggunakan password administrator. Pada saat Hoopah berjalan, kombinasi tombol yang bisa dipakai untuk keluar dari lingkungan Hoopah dinonaktifkan. Tombol-tombol seperti AltTab, Ctrl-Alt-Del dan Ctrl-Esc dimatikan. Anak-anak tidak akan menemukan cara untuk keluar dari lingkungan Hoopah.

Jumlah situs web yang telah disetujui oleh Hoopah jauh lebih kecil dibandingkan dengan KidZui. Orang tua bisa menambahkan daftar situs web yang diperbolehkan, mengidentifikasi usia anak yang sesuai untuk mengakses situs tersebut serta memilih kategori untuk situs web tersebut. Karena anak yang belum bisa membaca membutuhkan gambar untuk menampilkan sebuah website, maka Hoopah pun menampilkannya dalam bentuk gambar.

Konfigurasi yang dilakukan orang tua juga bisa mengizinkan anak untuk mengakses beberapa aplikasi windows. Namun sebagaimana halnya NoodleNet dan Peanut Butter PC, hal seperti ini bisa membawa resiko tersendiri. Melalui menu file open/save, anak dapat mengakses ke semua berkas di komputer, bahkan bisa mengakses windows explorer dan pada gilirannya bisa mengakses seluruh program di komputer. 
Tidak seperti KidZui dan Peanut Butter PC, Hoopah bisa membatasi waktu anak di depan komputer. Seperti NoodleNet, Hoopah bisa membatasi giliran tiap anak. Namun jika NoodleNet secara otomatis mengizinkan anak memakai komputer lagi setelah selang waktu tertentu, Hoopah memerlukan peran aktif orang tua untuk mengizinkan anak memakai komputer lagi.

\section{b. Email}

Orang tua bisa menyetel Hoopah agar anak bisa menggunakan email dan berhubungan dengan temannya menggunakan email tersebut. Syaratnya, akun email anak bisa diakses menggunakan POP 3 dan tidak memerlukan koneksi SSL. Dengan demikian akun Gmail tidak bisa digunakan karena memerlukan koneksi SSL. Orang tua juga bisa menentukan kontakkontak yang diperbolehkan untuk berhubungan dengan anak. Hanya kontak-kontak ini yang bisa mengirim email ke anak. Sedangkan pesan dari kontak-kontak yang lain akan dihapus atau bisa juga dialihkan ke akun email lain. Pengalihan ini diperlukan jika misalnya ada teman anak yang mengubah alamat emailnya.

Mengeklik kotak surat pada desktop Hoopah akan membuka kotak masuk dengan tampilan yang sederhana. Anak bisa mengeklik ikon pesan untuk membacanya. Untuk mengirim pesan, anak tinggal mengeklik pada ikon kontak yang ada. Email ini juga bisa dipakai untuk mengirin e-card, meskipun fasilitas untuk ini cukup terbatas.

Bagaimanapun, anak-anak yang sudah besar akan mulai jenuh dengan batasan-batasan dari Hoopah. Namun untuk anak yang masih kecil, agaknya Hoopah cukup bisa diandalkan.

\section{Peanut Butter PC}

Orang tua beresiko kehilangan berkas-berkas pentingnya ketika anak menggunakan komputer mereka. Peanut Butter PC mengizinkan anak memainkan game tertentu di komputer serta mengakses situs web yang aman.

Pada proses instalasi orang tua membuat nama log-in untuk semua anak-anak mereka. Orang tua juga bisa menentukan gambar untuk masingmasing anak tersebut. Namun gambar log-in ini harus disediakan sendiri, 
Peanut Butter PC (PBPC) tidak menyediakan gambar ikon seperti NoodleNet ataupun avatar seperti pada KidZui. Setelah itu orang tua harus menentukan program dan website yang diperbolehkan untuk anak berdasarkan data pada "start menu" dan "Internet Explorer Favourites". Selanjutnya PBPC siap untuk digunakan.

Pada dasarnya semua program dan situs web yang diizinkan dapat diakses oleh semua anak. Namun demikian orang tua dapat memberikan batasan yang berbeda-beda bagi tiap anak. Orang tua bisa mematikan fasilitas mencetak (print), memperbolehkan mencetak dari program saja, atau sekaligus memperbolehkan anak mencetak dari situs web. Orang tua juga dapat mengunci drive CD/DVD. Dengan demikian anak tidak bisa membuka drive CD/DVD. Jika orang tua memberikan batasan yang berbeda-beda untuk tiap anak, sebaiknya anak-anak yang lebih besar diberikan password pada akunnya.

PBPC bisa memblok pop-up maupun tautan yang berada di luar domain, namun orang tua harus menyetelnya per situs. Jika iklan-iklan pada sebuah situs tidak diperbolehkan untuk dilihat oleh anak, orang tua harus mematikan pop-up pada situs tersebut. PBPC tidak punya batasan dalam aksesnya ke internet, karena itu apabila di dalam situs web yang diizinkan terdapat tautan ke situs web lain yang tidak layak untuk anak, maka orang tua harus mengaktifkan pemblokiran terhadap tautan itu.

Orang tua harus menjalankan program PBPC secara manual sebelum menyerahkan penggunaan komputer kepada anaknya. Anak-anak bisa menggunakan komputer di lingkungan PBPC, namun tidak dapat keluar dari lingkungan tersebut. Sedangkan orang tua dapat keluar dari PBPC kapanpun dengan cara menekan kombinasi tombol rahasia dan memasukkan password.

Ketika digunakan, PBPC menyembunyikan desktop windows serta task bar-nya. PBPC juga mematikan tombol kombinasi papan ketik yang bisa digunakan untuk keluar dari lingkungan PBPC seperti Ctrl-Alt-Del (untuk membuka Task Manager), Alt-Tab (untuk beralih ke program lain), Alt-F4 (untuk menutup program yang sedang berjalan) dan Ctrl-Esc (untuk membuka menu start). PBPC mencegah aktivitas-aktivitas untuk keluar dari kontrol PBPC. Setelah masuk ke PBPC, anak mendapatkan desktopnya 
sendiri. Desktop sederhana ini berisi ikon-ikon dari program dan situs web yang bisa mereka akses. Mereka hanya bisa mengeklik ikon-ikon tersebut atau memilih keluar untuk memberi kesempatan bagi anak lain untuk menggunakan PBPC. Hanya satu program yang bisa dijalankan, tidak bisa dua program atau lebih dijalankan pada waktu bersamaan. Demikian juga halnya untuk situs web, tidak bisa dua situs web dikunjungi bersamaan. Peramban hanya memiliki fasilitas untuk maju, mundur atau keluar, tak ada fasilitas lain.

Desktop PBPC terlihat statis, kurang interaktif. Berbeda dengan KidZui dan NoodleNet yang memberikan efek animasi dan suara pada ikon-ikon di desktopnya, ikon PBPC hanya diam saja di tempatnya meskipun kursor tetikus terlihat berubah ketika melewati ikon-ikon tersebut.

Seperti NoodleNet, PBPC memperbolehkan anak memainkan game dan menjalankan program aplikasi Windows yang diizinkan oleh orang tua. Dalam kondisi seperti ini, tentu saja sangat mungkin anak memanfaatkan fasilitas dari sebuah program aplikasi untuk menjelajahi seluruh berkas yang ada di komputer. Bahkan anak bisa menghapus atau merusak berkas tersebut. Bahkan mereka juga bisa mengakses seluruh program apliaksi yang ada di komputer. Dengan demikian batasan yang diberikan tidak akan berguna lagi.

Orang tua juga harus selalu memantau situs-situs web yang dikunjungi oleh anak karena bisa saja tautan yang ada di dalam situs tersebut dipakai untuk mengakses ke dunia internet yang sangat luas, bisa jadi tautan-tautan itu menuju ke situs yang tidak aman untuk anak. Banyak situs menyertakan mesin pencari. Dari mesin pencari ini, anak bisa membuka situs web manapun yang mereka inginkan. KidZui dan NoodleNet memberikan batasan akses situs web hanya pada situs-situs yang layak bagi anak-anak saja. PBPC tidak menyediakan filter terhadap isi situs web. PBPC juga tidak menyediakan daftar situs web yang aman untuk anak. Dengan demikian peran orang tua menjadi sangat besar. Orang tua harus menyaring sendiri situs-situs yang diperbolehkan dan harus memblok setiap tautan yang menuju ke situs lain.

Memang banyak sekali kekurangan dari Peanut Butter PC, namun program ini sebenarnya diperuntukkan bagi anak-anak usia 3-6 tahun. Anak-anak pada usia itu cenderung belum banyak pengalaman dalam 
penggunaan komputer, sehingga batasan-batasan yang diterapkan orang tua diharapkan bisa efektif.

\section{NoodleNet}

Desktop windows merupakan awal dari penjelajahan ke dunia komputer dan internet. Banyak sekali aktivitas fantastis yang bisa dimulai dari sana. Setiap orang dapat menjelajah ke manapun dia mau dari desktop ini. Karena itulah banyak orang tua yang khawatir atas dunia luas yang terbuka dari desktop. Mereka khawatir anak-anak akan tersesat ke dunia yang seharusnya belum boleh mereka jelajahi. NoodleNet menutup jendela desktop ini seluruhnya, kemudian menggantikannya dengan lingkungan baru yang hanya mengizinkan anak untuk mengakses situs web dan permainan online yang telah disortir dan disesuaikan untuk anak berusia 3-11 tahun.

Untuk menginstal NoodleNet diperlukan komponen-komponen pendukung yaitu: NET Framework, Flash, Shockwave, Windows Media Player dan Quick Time. Apabila komponen-komponen ini belum terinstal, NoodleNet akan meminta agar komponen-komponen tersebut diinstal terlebih dahulu. Jika instalasi NoodleNet telah berhasil, maka NoodleNet akan berfungsi secara penuh.

NoodleNet mendefinisikan tiga buah akun untuk anak dengan batasan usia 3-5 tahun, 6-8 tahun dan 9-11 tahun. Orang tua bertugas untuk membuat akun ini dan memasukkan tanggal lahir anak agar NoodleNet dapat membedakan usia mereka. Ada lima akun yang bisa aktif dalam waktu yang sama. Masing-masing akun memiliki password. Uniknya, NoodleNet menyediakan password dalam bentuk gambar. Ada lebih dari 150 gambar yang bisa dipilih untuk menjadi password. Kalau masih kurang, bisa juga berkas gambar yang ada di komputer dijadikan sebagai password. Anak-anak yang sudah besar bisa diberikan password dalam bentuk teks.

Produk parental control lain seperti Net Nanny dan Safe Eyes memberikan fasilitas untuk menjadwalkan waktu-waktu yang diperbolehkan bagi anak untuk mengakses internet. Orang tua juga bisa menentukan batas waktu maksimum harian atau mingguan. NoodleNet menyediakan fasilitas yang berbeda. Orang tua harus menentukan batas waktu maksimum bagi 
tiap anak untuk mengakses internet. Orang tua juga harus menentukan batas waktu minimum NoodleNet dalam kondisi mati sebelum digunakan kembali untuk sesi berikutnya. Namun kelemahannya, apabila anak keluar dari satu sesi sebelum waktunya berakhir, kemudian anak masuk lagi, maka waktu akan dihitung ulang. Hal ini bisa dimanfaatkan untuk mendapatkan waktu lebih dari yang ditentukan oleh orang tua. Ada satu kelemahan lagi terkait dengan menu konfigurasi. Apabila orang tua masuk ke halaman konfigurasi, mengubah setelan konfigurasi, kemudian keluar dari laman tersebut tanpa memencet tombol "save", maka perubahan setelan konfigurasi tersebut akan hilang.

Antarmuka NoodleNet sangat bervariasi tergantung usia penggunanya. Untuk anak usia 3-5 tahun, tampilan antarmuka berupa layar dengan gambar penuh warna yang memperbolehkan anak untuk mengakses sedikit situs web yang telah direview oleh tim NoodleNet. Anak juga bisa bermain game yang sesuai dengan usia mereka, mendengarkan musik, membaca buku, ataupun menonton video secara online.

Untuk anak usia 6-8 tahun tampilan antarmuka menggunakan lebih banyak teks dan lebih sedikit gambar. Lebih banyak situs web yang bisa dijelajahi. Variasinyapun lebih banyak. Sedangkan untuk anak berusia 9-11 tahun, tampilan antarmuka seperti tampilan teknologi tinggi di dunia bisnis, namun tetap dengan batasan akses web sesuai dengan umur anak. Ketika anak mencapai kelompok usia di atasnya, maka secara otomatis NoodleNet mengubah tampilan antarmuka sesuai dengan kelompok umur tersebut. NoodleNet menghitung umur anak berdasarkan data tanggal lahirnya.

Untuk menciptakan lingkungan yang aman, NoodleNet menonaktifkan Ctrl-Alt-Del, tombol windows dan tombol-tombol lain yang dapat digunakan untuk keluar dari lingkungan NoodleNet. Satu hal yang bisa dilakukan anak selain mengunjungi situs web yang telah disetujui adalah melakukan pencarian menggunakan mesin pencari yang aman. Anak bisa melihat semua hasil pencarian, namun tidak bisa membuka situs yang tidak ada dalam daftar persetujuan NoodleNet. Hanya situs yang ada dalam daftar NoodleNet saja yang bisa dibuka. Cara seperti ini membuat anak tetap berada dalam zona aman. Akan tetapi sebagian anak barangkali akan frustasi ketika berkali-kali tidak bisa membuka situs web yang mereka inginkan. 
NoodleNet tidak seperti banyak program parental control yang langsung dijalankan ketika komputer dihidupkan. Orang tua harus masuk ke windows sebelum menjalankan NoodleNet. Ketika NoodleNet sudah berjalan, barulah anak mendapatkan giliran untuk mengunakan komputer. NoodleNet tidak mengizinkan anak keluar dari program dengan cara me-restrat komputer.

Lingkungan NoodleNet yang serba dibatasi barangkali akan membuat jenuh anak yang sudah agak besar. Orang tua dapat memberikan kebebasan lebih kepada mereka dengan menambahkan daftar situs web yang boleh untuk dikunjungi. Orang tua dapat memasukkan alamat situs web secara langsung. Cara lain adalah dengan cara mencari alamat situs web menggunakan mesin pencari, kemudian memasukkan hasil pencarian ke dalam daftar yang diizinkan dengan mengeklik sebuah tombol.

Mengizinkan sebuah situs untuk bisa dibuka oleh anak bukan berarti memberi kebebasan penuh kepada anak untuk berselancar di dunia maya. Anak bisa menjelajah ke laman-laman yang masih berada dalam satu domain. Mengeklik banner ataupun tautan di dalamnya tidak akan dapat menuju ke situs web yang bersangkutan jika situs tersebut tidak ada dalam daftar yang diizinkan oleh NoodleNet. Pengalaman berselancar menggunakan NoodleNet tidak akan sama dengan berselancar menggunakan Internet Explorer ataupun Firefox. Tidak ada klik kanan, tidak ada menu option, tidak ada status bar di bagian bawah yang menunjukkan proses yang sedang berlangsung atau menunjukkan tautan yang dituju. Orang dewasa barangkali tidak akan menyukainya, tetapi anak-anak mungkin tidak akan merasa keberatan.

Anak-anak yang sudah besar barangkali akan mendapatkan tugas dari sekolah yang harus dikerjakan menggunakan komputer. Misalnya membuat sebuah cerita yang harus diketik. Untuk keperluan semacam ini, NoodleNet menyediakan fasilitas untuk mengizinkan anak mengakses program-program tertentu yang diizinkan oleh orang tua. Namun apabila hal ini dilakukan, kemungkinan anak lepas dari kontrol NoodleNet sangat besar. Dari menu file anak dapat masuk ke windows explorer untuk kemudian menjelajah berkas-berkas yang ada di dalam komputer. Melalui windows explorer anak juga bisa mengakses program-program yang lain, 
bahkan bisa mematikan NoodleNet itu sendiri. Padahal anak-anak biasanya sangat pandai dan cepat sekali belajar.

Anak-anak yang berada dalam lingkungan NoodleNet memang akan terhindar dari situs web yang tidak baik. Juga tidak bisa mengakses berkasberkas di komputer. Namun dengan begitu, anak menjadi tidak punya pengalaman bekerja dengan windows yang sesungguhnya beserta aplikasiaplikasinya.

NoodleNet tidak menyediakan browsing history yang bisa dicek oleh orang tua, juga tidak menyediakan fasilitas peringatan untuk orang tua. Hal ini dikarenakan anak tidak bisa mengakses situs-situs yang tidak layak, sehingga browsing history dan fasilitas peringatan dianggap tidak diperlukan.

\section{Kesimpulan}

Peramban-peramban web khusus anak yang diulas dalam tulisan di atas masing-masing memiliki kelebihan dan kekurangan. KidZui memiliki kelebihan dalam tampilannya yang dinamis. KidZui juga dilengkapi dengan sistem pemfilteran terhadap web yang tidak layak untuk anak. Pengelompokan situs web menjadi beberapa kategori juga mempermudah anak untuk mengakses situs web yang mereka inginkan. Fitur jejaring sosial juga memungkinkan anak berinteraksi dengan teman-teman sesama pengguna KidZui. Namun KidZui tidak dilengkapi dengan fitur yang mengizinkan anak untuk memakai program aplikasi yang lain. KidZui juga tidak menerapkan pembatasan waktu bagi anak dalam menggunakan komputer. Peramban KidZui tersedia dalam versi gratis dan versi premium.

Hoopah Kidview Computer Explorer memiliki tampilan bergambar yang bisa menyesuiakan dengan usia anak. Begitu anak mencapai kelompok umur yang lebih tinggi, tampilan Hoopah akan berubah, demikian juga pembatasan akses terhadap internet menjadi semakin longgar. Sistem pemfilteran juga menjadi satu fasilitas yang tak ketinggalan. Hoopah memblok tampilan pop-up dan banner iklan. Situs web juga dikelompokkan ke dalam beberapa kategori. Hoopah dilengkapi dengan software untuk menggambar. Fasilitas lain yang dimiliki Hoopah adalah pembatasan waktu anak dalam mengakses internet. Dengan menggunakan Hoopah, orang tua juga bisa mengontrol email anak. 
Tampilan Peanut Butter PC (PBPC) terlihat lebih statis sehingga agak membosankan. Sistem filter PBPC sangat longgar, sehingga anak-anak mungkin bisa masuk ke situs lain dengan cara mengeklik tautan yang ada dalam situs yang diizinkan. Peran orang tua harus lebih besar di sini untuk membatasi agar anak tidak menjelajah terlalu jauh. PBPC juga memperbolehkan anak untuk memakai program-program aplikasi lain yang telah diizinkan oleh orang tua.

NoodleNet dapat membedakan kelompok umur anak. Tampilannya juga menyesuaikan dengan usia anak. Sistem penyaringan juga diterapkan pada peramban ini. Tautan luar yang berada diluar domain web yang diizinkan otomatis diblok. NoodleNet tidak hanya membatasi waktu anak berada di depan komputer, tetapi juga memberi batas waktu minum agar NoodleNet dalam keadaan mati sebelum anak mulai berselancar lagi. Beberapa program aplikasi bisa digunakan oleh anak jika orang tua mengizinkannya.

Semua software yang telah dibahas bisa dijadikan alternatif untuk membentengi anak dari konten negatif internet. Akan tetapi tidak ada satu perambanpun yang tanpa kekurangan. Pembatasan yang dilakukan menjadi tidak efektif ketika ada program aplikasi yang diizinkan untuk digunakan oleh anak, karena dengan begitu bisa saja anak mendapatkan akses penuh ke dunia maya. Untuk itu perlu memasang peramban web khusus anak saja tidaklah cukup. Agar keamanan anak dalam berselancar di dunia maya lebih terjaga barangkali diperlukan beberapa metode tambahan. Bisa dengan mengaktifkan parental control di sistem operasi, menginstal perangkat lunak khusus parentak control, menambahkan fasilitas parentak control pada peramban ataupun dengan mencoba menggunakan DNS Nawala Project.

Pembatasan yang dilakukan oleh peramban web khusus anak juga berarti membatasi ruang belajar anak. Untuk itu peran orang tua sangat diperlukan agar anak mendapatkan ruang belajar yang luas tapi sekaligus bisa mengakses dunia maya secara aman.] 


\section{Daftar Pustaka}

Ambarwati, Katharina dan Muji Sulistyowati, "Internet dan Perilaku Seksual Remaja," The Indonesian Joumal of Public Health ISSN: 1829-7005 Vol. 2 / No. 1 / 2005-07.

Aryani S., Kandi, "Penerimaan Remaja terhadap Wacana Pornografi dalam Situs-situs Seks di Media Online," Jumal Penelitian Dinamika Sosial ISSN: 1411-6383 Vol. 7 -No. 2 / 2008-08.

Aryani, Kandi, "Analisis Penerimaan Remaja terhadap Wacana Pornografi dalam Situs-situs Seks di Media Online," Jumal Masyarakat, Kebudayaan dan Politik ISSN: 2086-7050 Vol. 19 / No. 2 / 2006-04.

Candra, Puspita Adiyani, "Penggunaan Internet pada Anak-anak Sekolah Usia 612 Tahun di Surabaya", Jumal Commonline Vol. 1 -No. 2 / 2013-02.

http://tekno.kompas.com/read/2012/11/01/1110452/pengguna.internet.di.ind onesia.capai.55.juta, diakses pada 1 April 2013.

http://tekno.kompas.com/read/2012/10/01/1108555/quotjalur.bebasquot.akse s.konten.porno.banyak.dicari.anak, diakses pada 1 April 2013.

http://tekno.liputan6.com/read/467387/2012-pengguna-internet-indonesiacapai-63-juta, diakses pada 1 April 2013.

http://www.pcmag.com/article2/0,2817,2325577,00.asp, diakses pada 1 April 2013.

http://www.apjii.or.id/index.php?option=com_content\&view=article\&id=59\&I temid=53, diakses pada 1 April 2013 .

Novianto, Iik, "Perilaku Penggunaan Internet di Kalangan Mahasiswa (Studi Deskriptif tentang Perilaku Penggunaan Internet di Kalangan Mahasiswa Perguruan Tinggi Negeri (FISIP Unair) dengan Perguruan Tinggi Swasta (FISIP UPN) untuk Memenuhi Kebutuhan Informasinya)", Jumal Libri-Net Vol. 2 - No. 1 / 2013-01.

Rochmawati, Weny, "Perilaku Pemanfaatan Internet (Internet Utilization of Behavior) (Studi Deskriptif tentang Pemanfaatan Internet untuk Kepentingan Hiburan dan Akademik di Kalangan Anak-anak di Kota Surabaya)", Jumal Libri-Net Vol. 1 - No. 1 / 2012-12. 